\title{
MINERAL-MICROBE INTERACTIONS: BACTERIALLY INDUCED HYDRATION OF BIOTITE
}

\author{
HU, R. ${ }^{1}-$ LI, S. ${ }^{1}-$ LI, F. ${ }^{1 *}-$ YANG M. ${ }^{1}-$ JIN,$Z^{2}{ }^{2}-$ LI, X. ${ }^{1}-$ ZHANG, F. ${ }^{2}$ \\ ${ }^{I}$ College of Resources and Environmental Sciences, Nanjing Agricultural University, Nanjing, \\ Jiangsu 210095, China
}

${ }^{2}$ State Key Laboratory of Loess and Quaternary Geology, Institute of Earth Environment, Chinese Academy of Sciences, Xi'an, Shaanxi 710075, China

*Corresponding author

e-mail:fchli@njau.edu.cn; phone: +86-25-8439-5014

(Received $11^{\text {th }}$ Feb 2020; accepted $22^{\text {nd }}$ May 2020)

\begin{abstract}
The interaction between microbes and minerals occurring in the soil is an important geochemical process in the Earth's surface system. Investigating the weathering of potassium-bearing silicate minerals by microorganisms is of great importance in understanding the process of soil development and the provision of nutrient for plants. One of the major gaps in studies of weathering is the lack of sufficient evidence from X-ray diffraction to indicate of the formation of secondary minerals in the weathering of primary minerals. The present study aims to investigate whether or not secondary minerals formed during laboratory experiments can be detected by XRD (X-ray diffraction, XRD). For this reason, a series of culture experiments using biotite and Paenibacillus mucilaginous strain YM-1 were performed over a period of 450 days. The results demonstrate that preliminary treatment by sedimentation-centrifugation according to Stokes's law to enrich the fine particles with grain size less than $1 \mu \mathrm{m}$ and subsequent detection by XRD are practicable methods for investigating the presence of secondary minerals. The XRD results of the fraction with grain size less than $1 \mu \mathrm{m}$ indicated that a part of the biotite flakes altered into hydrobiotite on day 60 in experiments with strain YM-1, while hydrobiotite occurred on day 390 for experiments without bacteria. In summary, it is demonstrated that strain YM-1 of Paenibacillus mucilaginous evidently accelerated biotite weathering.
\end{abstract}

Keywords: fraction of fine particles, bioweathering, Paenibacillus mucilaginous, sedimentationcentrifugation, enrichment method

\section{Introduction}

The weathering of primary silicate minerals is of great importance for resolving many problems related to soil sciences and geochemistry. Firstly, clay minerals are the dominant weathering residues of primary silicates, and their formation and subsequent transformation helps bring to light the development of the soil (Kretzschmar et al., 1997). Secondly, cations released from minerals by weathering are an important source of nutrient elements for plants (Kretzschmar et al., 1997; Föllmi et al., 2009). Thirdly, mineral weathering on the continental surface controls the chemical composition of groundwater, rivers, lakes, and oceans over long timescales (Bonneville et al., 2011).

Biotite, as a representative of primary phyllosilicate minerals, exists extensively in different rocks, sediments and soils. In the past three decades, the weathering process (Banfield and Eggleton, 1988; Banfield and Murakami, 1998; Emberson et al., 2017) and weathering rate of biotite (Murphy et al., 1998; White, 2003) in the field and the effects of $\mathrm{pH}$ and temperature on dissolution kinetics in the laboratory (Kalinowski and Schweda, 1996; Murakami et al., 2003 ; Samson et al., 2005; Bray et al., 2015; Webb 
and Girty, 2016) have been investigated. The chemical weathering process and rate of biotite have been investigated also in the laboratory (Kalinowski and Schweda, 1996; Murakami et al., 2003; Bray et al., 2015; Tamrat et al., 2018), and several studies have suggested that microorganisms selectively colonize and weather minerals for nutritional purposes (Bennett et al., 2000; Rogers and Bennett, 2004). For example, Paenibacillus mucilaginosus and $P$. edaphicus selectively weather $\mathrm{K}$-bearing silicate minerals (Ehrlich, 1996; Barker et al., 1998). The first direct indications that microorganisms enhance biotite weathering were found by Frankel (1977). Subsequently, a large number of studies have shown that microbes accelerate the elemental release from biotite (Baker et al., 1998; Balogh-Brunstad et al., 2008; Ward et al., 2013; Ahmed and Holmstrom, 2015). Many works have also suggested that microbial metabolism not only observably accelerates element release from primary silicates (Balogh-Brunstad et al., 2008; Zavarzina et al., 2016; Setiawati and Mutmainnah, 2016), but also effectively induces the formation of secondary minerals (Fortin and Beveridge, 1997; Murakami et al., 2003).

Several indications of biotite weathering into kaolinite (Ahn and Peacor, 1987), vermiculite (Banfield and Eggleton, 1988) and kaolinite + halloysite (Dong et al., 1998) have been found using transmission electron microscopy in the course of chemical or biological weathering experiments under laboratory conditions. Secondary minerals observed by TEM (transmission electron microscopy, TEM) are commonly seen as microscopic granules, but not only is it difficult to determine the quantities of secondary minerals in a sample, it is also difficult to ascertain whether or not they have been newly formed during weathering experiments. Although, fortunately, XRD technology allows secondary minerals to be detected, it is possible that they might only be detected in weathering residues if they are present in sufficient quantities.

Few previous studies have focused on the detection of secondary minerals by XRD. In the present work, a batch of weathering experiments was carried out over 450 days using biotite and $P$. mucilaginous strain YM-1 bacteria isolated from a soil sample. Grains smaller than $1 \mu \mathrm{m}$ were examined by XRD with the aim of clarifying if the amount of secondary minerals formed during weathering of biotite is sufficient for detection by XRD. We hope to find a more efficient and precise method to get information about the formation of secondary minerals than the previous applied process.

\section{Materials and methods}

\section{Characteristics of the biotite sample}

The biotite sample used in this study was provided by Rentang Company Limited, Nanjing, China. The original biotite flakes have a maximum size of about $15 \mathrm{~cm} \times$ $15 \mathrm{~cm}$, and are black-brown in color. The flakes were cut into approximately $1 \mathrm{~cm} \times$ $1 \mathrm{~cm}$ squares using a steel forfex, and ground in an agate mortar. Flakes $>100$ mesh $(0.15 \mathrm{~mm})$ and $<65$ mesh $(0.25 \mathrm{~mm})$ were obtained by a dry sieving. The chemical composition of the sample, determined by XRF (X-ray fluorescence spectrometer, $\mathrm{XRF}$ ), was as follows (wt\%): $\mathrm{SiO}_{2} 36.41, \mathrm{Al}_{2} \mathrm{O}_{3} 21.31, \mathrm{FeO}+\mathrm{Fe}_{2} \mathrm{O}_{3} 24.43, \mathrm{MgO} 5.43$, $\mathrm{CaO} 0.05, \mathrm{~K}_{2} \mathrm{O} 9.15, \mathrm{Na}_{2} \mathrm{O} 0.19, \mathrm{TiO}_{2} 1.54$ and $\mathrm{MnO} 0.55$, total $99.06 \%$ including a $1.44 \%$ loss on ignition. In addition, the fluorine (F) content determined by an anion selective electrode was $0.96 \mathrm{wt} \%$. 


\section{Isolation and identification of bacteria}

The bacteria used in the culture experiments were obtained from local soil. A soil sample (alfisols, $\mathrm{pH}$ 6.40) was taken $7-10 \mathrm{~cm}$ beneath the ground surface from farmland at Qilinmen, Nanjing, Jiangsu Province, China $\left(32^{\circ} 03^{\prime} 18^{\prime \prime} \mathrm{N}, 118^{\circ} 55^{\prime} 21^{\prime \prime} \mathrm{E}\right)$, a normal farmland with no special plants. In this study, a SB (Super Broth, SB) solid medium was used for bacterial selection, enrichment and purification. The biotite weathering tests were performed in a SB liquid medium. The composition of the solid medium was: $5 \mathrm{~g}$ sugar, $2 \mathrm{~g} \mathrm{Na}_{2} \mathrm{HPO}_{4}, 0.5 \mathrm{~g} \mathrm{MgSO}_{4} \cdot 7 \mathrm{H}_{2} \mathrm{O}, 0.01 \mathrm{~g} \mathrm{CaCO}_{3}$ and $18 \mathrm{~g}$ agar per liter of deionized water. The liquid medium was obtained from the solid medium using $0.5 \mathrm{~g}$ yeast-displacing agar. One strain, denoted YM-1, was isolated from the soil sample. The bacterial colonies were colorless and hemispherical with a smooth surface. The YM-1 bacterial cells are rod-shaped with diameters ranging from 0.8 to $1.3 \mu \mathrm{m}$ and $2.5-$ $5.5 \mu \mathrm{m}$ long (Fig. 1). Gram staining showed that strain YM-1 is gram-negative. Strain YM-1 was identified as being closely related to Paenibacillus mucilaginous $480 \mathrm{D}^{\mathrm{T}}$ (AF006077) (Shelobolina et al., 1997) with 99.72\% similarity, based on comprehensive phylogenetic analyses of 16S rRNA gene sequences (Fig. 2). Login number on NCBI is JF499917 for strain YM-1.

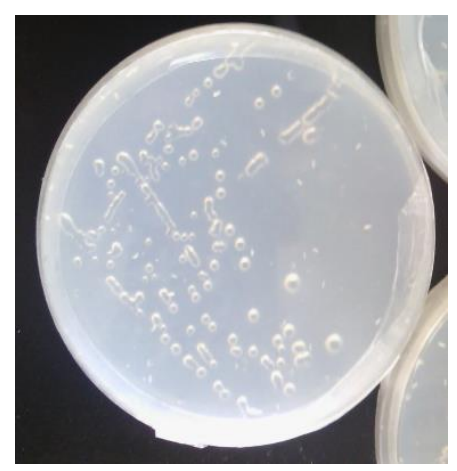

a

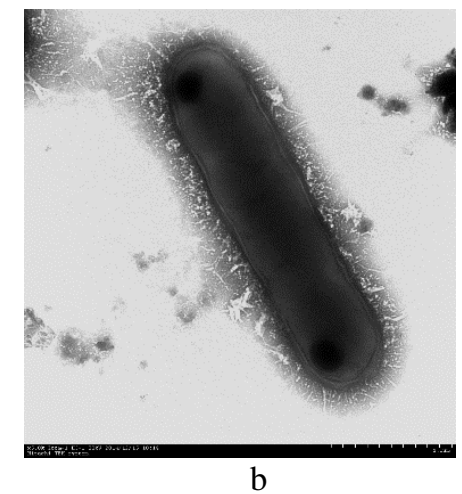

b

Figure 1. The morphology of the YM-1 bacterial. (a) The morphology of the colony grown on the medium; (b) the morphology of the bacterial cell grown on the solid medium after four days

\section{Experimental methods}

Several colonies of strain YM-1 were selected and dissolved in $300 \mathrm{ml}$ of the liquid medium, and a seed culture was obtained after $48 \mathrm{~h}$ incubation at $30^{\circ} \mathrm{C}$ and $180 \mathrm{rpm}$ on a rotary shaker. Then $48 \mathrm{ml}$ of the liquid medium ( $\mathrm{pH}$ about 7.4 ) and $500 \mathrm{mg}$ of the biotite powder were dispensed into $250-\mathrm{ml}$ sterile conical flasks. All flasks were autoclaved at $121^{\circ} \mathrm{C}$ for $20 \mathrm{~min}$. After cooling to room temperature, a 2-ml aliquot of seed culture was added to the flasks. The bacterial density was found to be about $4.52 \times 106 \mathrm{cfu} / \mathrm{ml}$ in the initial culture. The flasks were incubated at $28{ }^{\circ} \mathrm{C} \pm 0.5{ }^{\circ} \mathrm{C}$ in still conditions, and periodically shaken by hand each day. Single tests were ceased every five days up to the 30th day, then every 30 days until the 450th day. To maintain bacterial activity, $2 \mathrm{ml}$ of fresh seed culture was added to the remaining sample flasks every 30 days. All tests were carried out in triplicate. Simultaneously, a batch of CK (control check, CK) tests without bacteria was performed for comparison. When each test was complete, the liquid and solid constituents were separated using the sedimentation-centrifugation method in accordance with Stokes's law. 


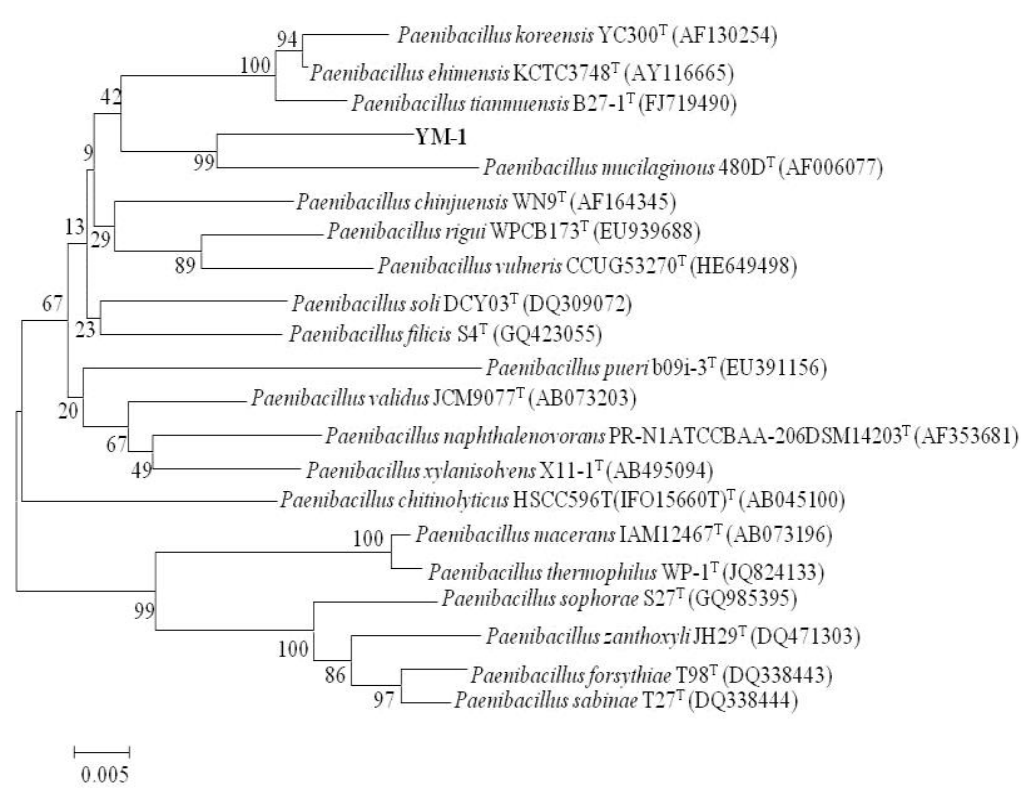

Figure 2. Phylogenetic tree of strain YM-1 based on 16S rRNA gene sequence comparison within related genus

The tests that were stopped prior to and including the 60th day were mainly used to determine bacterial density and $\mathrm{pH}$; after 60 days the samples were tested by XRD to detect secondary mineral formation during the weathering process. To obtain the fine particles necessary to do this the $<1 \mu \mathrm{m}$ fraction was separated from the solid constituent by sedimentation-centrifugation, then transferred to a glass slide and dried at room temperature for oriented particle specimens.

\section{Observation and measurement}

The plate count method was used for bacterial enumeration (Huang et al., 2013). The $\mathrm{pH}$ of the solution was measured with a $\mathrm{pH}$ meter (pHS-3C, KangYi Instrument co., China). XRD (Rigaku D/Max-B (III), Japan) with $\mathrm{Cu}-\mathrm{K} \alpha$ radiation was used to identify the mineral species. Each sample was scanned continuously at $2^{\circ}(2 \theta)$ min- 1 , from $3^{\circ}$ to $60^{\circ}(2 \theta)$ at $35 \mathrm{kV}$ and $20 \mathrm{~mA}$ in $0.01^{\circ}(2 \theta)$ steps. Qualitative identification of the mineral composition was performed using Jade 6.0 software. An TEM (H-7650, Hitachi, Japan) was used to observe the morphology of the bacteria. Several colonies suspended in double-distilled water were dropped onto a copper mesh. The dried sample was stained with phosphotungstic acid for $30 \mathrm{~s}$ and dried before TEM imaging. An EVO18-type scanning electron microscope (EVO18-type, Carl Zeiss, Germany) equipped with an energy dispersive detector was used for imaging the minerals and analyzing their chemical compositions. The dried samples were coated with $8 \mathrm{~nm}$ of gold before SEM (scanning electron microscope, SEM) imaging.

\section{Results}

\section{Change of bacterial density and $\mathrm{pH}$}

The temporal curve in Figure 3 shows that bacterial density increased with incubation time and peaked at $93.67 \times 10^{6} \mathrm{cfu} / \mathrm{ml}$ on day 25 , then decreased gradually to 
$17.24 \times 10^{6} \mathrm{cfu} / \mathrm{ml}$ on day 60 . Conversely, the $\mathrm{pH}$ gradually decreased in the initial stage until day 30 (5.86), then began to rise slowly until day 60 .

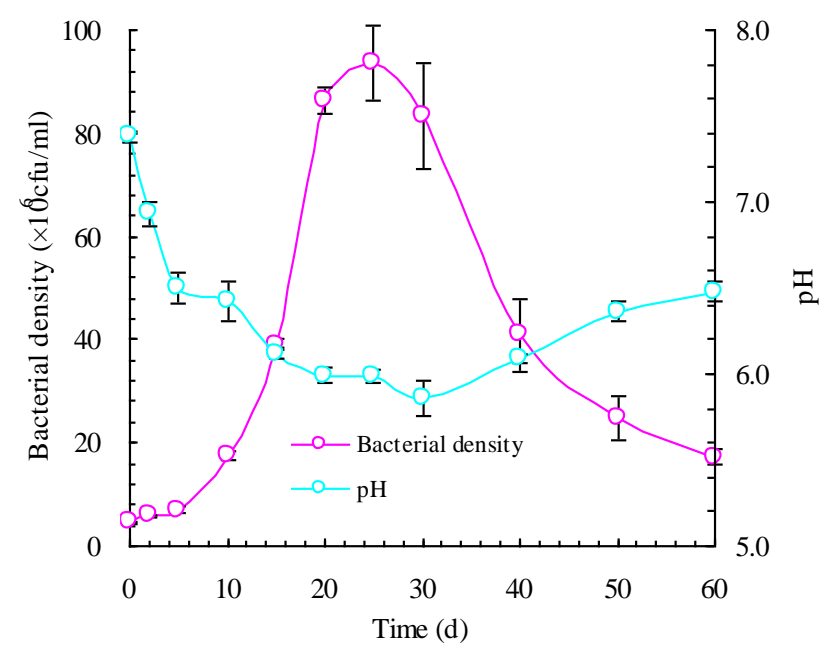

Figure 3. Temporal changes of bacterial density and $p H$

\section{The occurrence of secondary minerals}

The XRD results showed that the diffraction peak (d between 1.0999 and $1.4903 \mathrm{~nm}$ ) appeared in the patterns of the samples on and after day 30 (Fig. 4; Table 1). This suggests that a part of the biotite flakes may have been altered to hydrobiotite. The abiotic experiments showed a diffraction peak of secondary minerals on and after day 390 (Fig. 5; Table 1). This indicates that secondary minerals also formed in abiotic conditions, but that their formation evidently occurred later than in the biotic experiments.

Table 1. $d$ value of diffraction peak of the hydrobiotite and percentage of vermiculite in the hydrobiotite

\begin{tabular}{c|c|c|c|c}
\hline \multirow{2}{*}{ Time (d) } & \multicolumn{2}{|c|}{ Biotic experiments } & \multicolumn{2}{c}{ Abiotic experiments } \\
\cline { 2 - 5 } & d value (nm) & Vermiculite (\%) & d value (nm) & Vermiculite (\%) \\
\hline 30 & - & - & $/$ & $/$ \\
60 & 1.1085 & 29.8 & $/$ & - \\
90 & 1.1189 & 32.3 & - & - \\
120 & 1.1692 & 44.0 & - & $/$ \\
150 & 1.1136 & 31.0 & $/$ & $/$ \\
180 & 1.143 & 31.2 & $/$ & $/$ \\
210 & 1.1042 & 28.7 & - & - \\
240 & 1.1129 & 30.9 & - & - \\
270 & 1.0999 & 27.6 & $/$ & - \\
300 & 1.2543 & 61.7 & - & - \\
330 & 1.3954 & 86.2 & - & 94.5 \\
360 & 1.4085 & 88.2 & 1.4506 & 97.2 \\
390 & 1.4076 & 88.1 & 1.4698 & 95.8 \\
420 & 1.4903 & 100.0 & 1.4602 & / \\
450 & 1.4685 & 97.0 &
\end{tabular}

"_-" denotes absence of new diffraction peak; "/" denotes that the particle fraction with grain size of less than $1 \mu \mathrm{m}$ was not obtained 

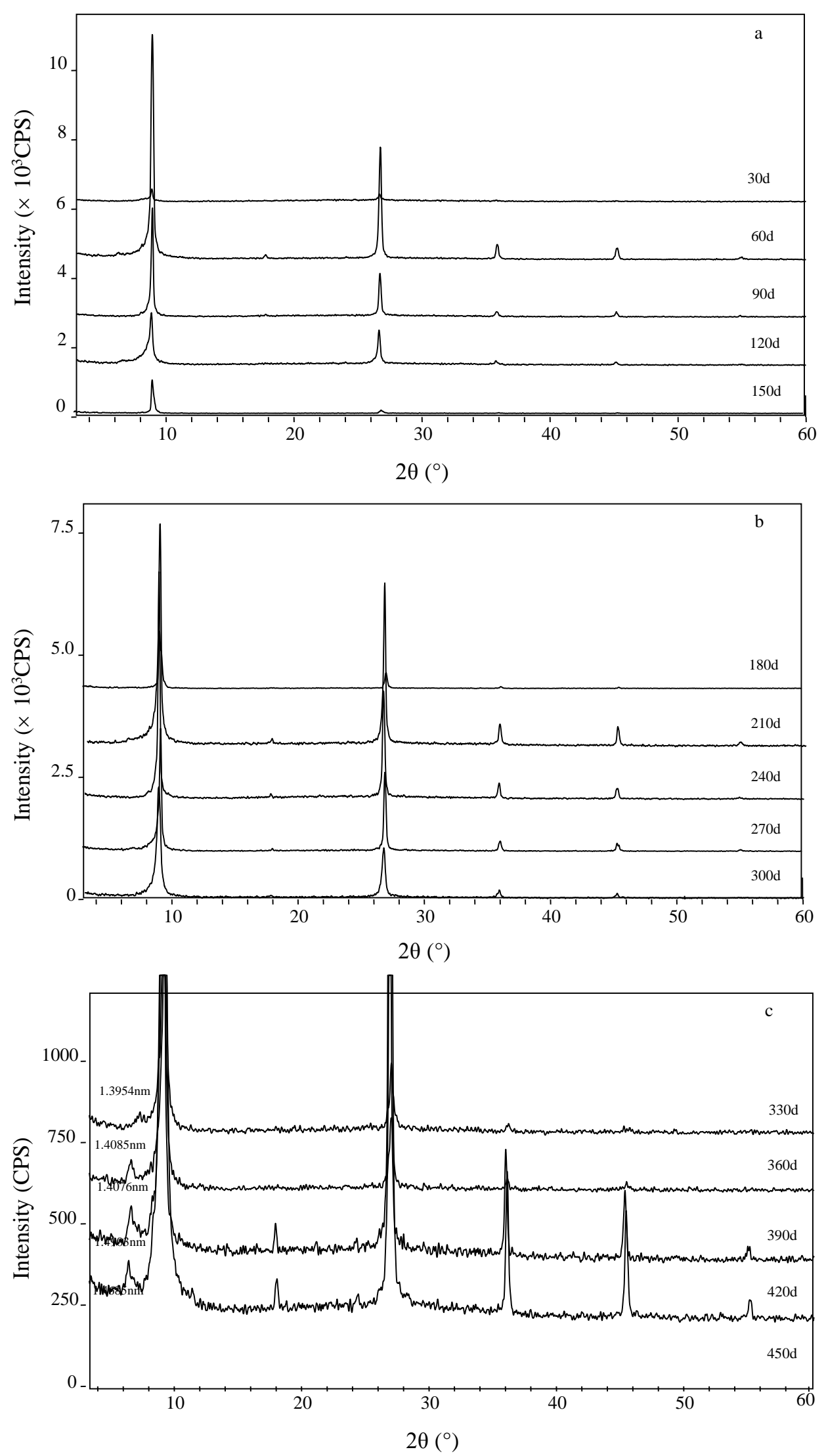

Figure 4. Representative XRD patterns of the $<1 \mu \mathrm{m}$ fraction in the biotic experiments 


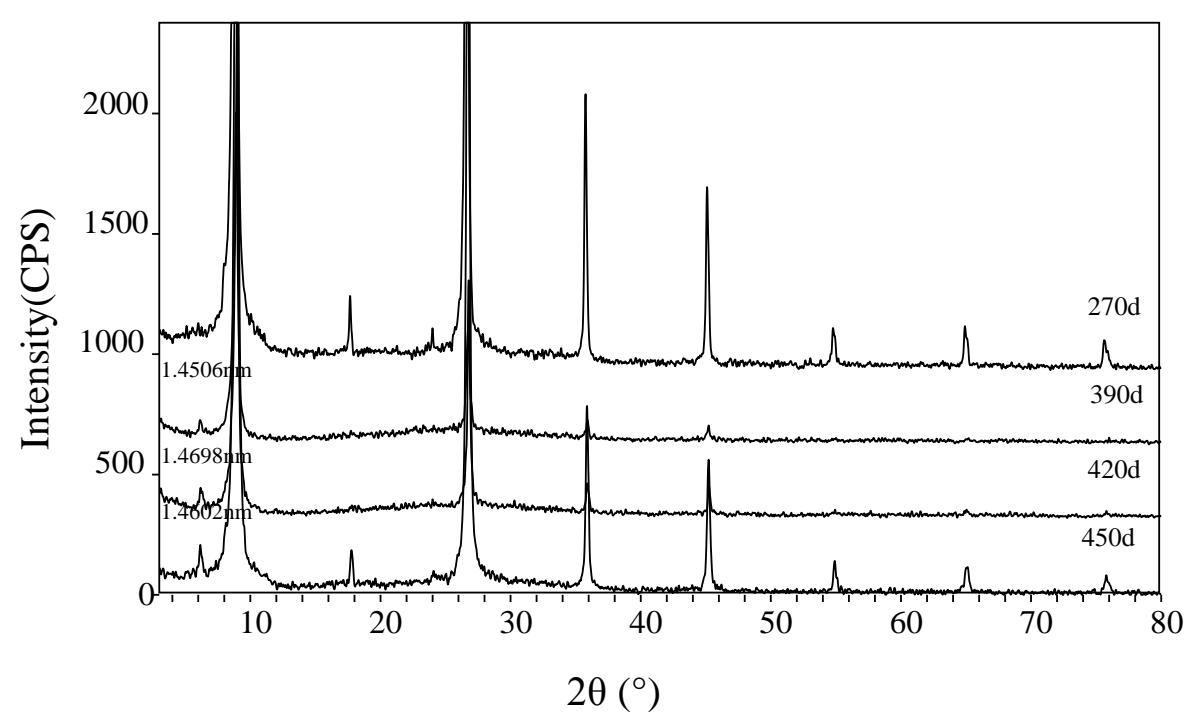

Figure 5. Representative XRD patterns of the $<1 \mu \mathrm{m}$ fraction in the abiotic experiments

Bacterial cells (Fig. 6a) and mineral fragments (Fig. 6b) were observed by SEM. The EDS (energy dispersive detector, EDS) results indicated that these fine fragments mainly consisted of $\mathrm{Si}, \mathrm{Al}, \mathrm{Fe}, \mathrm{Mg}$ and $\mathrm{K}$, which when considered together with the XRD results, suggested that the hydrobiotite may be composed of biotite layers and vermiculite layers.
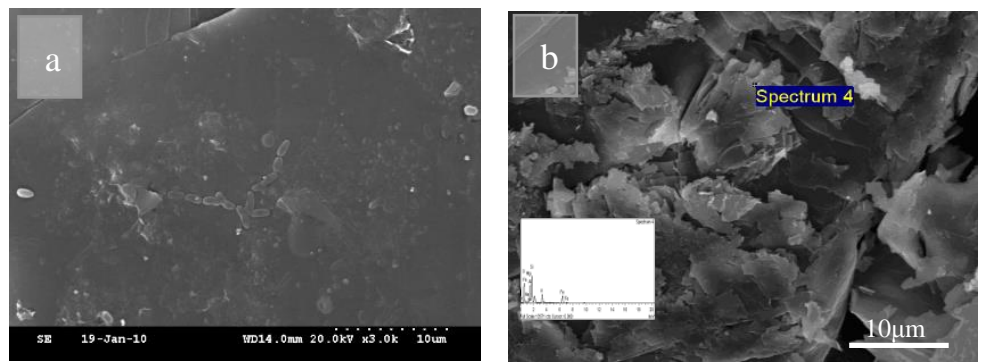

Figure 6. SEM images and the EDS pattern of the solid particles after incubation 330 days. (a) Several bacterial cells arrayed as chain on the surface of biotite flakes; (b) several mineral particles consisted mainly of Si, Al, Fe, $\mathrm{Mg}$ and $\mathrm{K}$

\section{Discussion}

\section{Content of vermiculite in the hydrobiotite}

To quantitatively describe the vermiculite content in the hydrobiotite, we introduce Equations 1 and 2, which are applicable to mixed layer minerals (Lu, 1993):

$$
\begin{gathered}
1 / d_{N}=\alpha / d_{B}+\beta / d_{V} \\
\alpha+\beta=100 \%
\end{gathered}
$$

where $d_{N}$ is the $d_{001}$ value of the mixed layer mineral; $d_{B}$ and $d_{V}$ are the $d_{001}$ values of biotite $(=1.00 \mathrm{~nm}$ for samples in this study) and vermiculite (commonly $=1.49 \mathrm{~nm})(\mathrm{Xu}$ 
and Cao, 1993), respectively; and $\alpha, \beta$ are the percentages of vermiculite and biotite layers in the hydrobiotite flakes, respectively. The calculation results are listed in Table 1 . The percentage of vermiculite layer gradually increased with incubation time from approximatively $30 \%$ on day 60 to about $100 \%$ on day 420 (Fig. 7) - that is, biotite changed into vermiculite stage by stage throughout the biotite-vermiculite interstratified mineral. This confirmed that hydrobiotite may be an intermediate product in the transformation process from biotite into vermiculite.

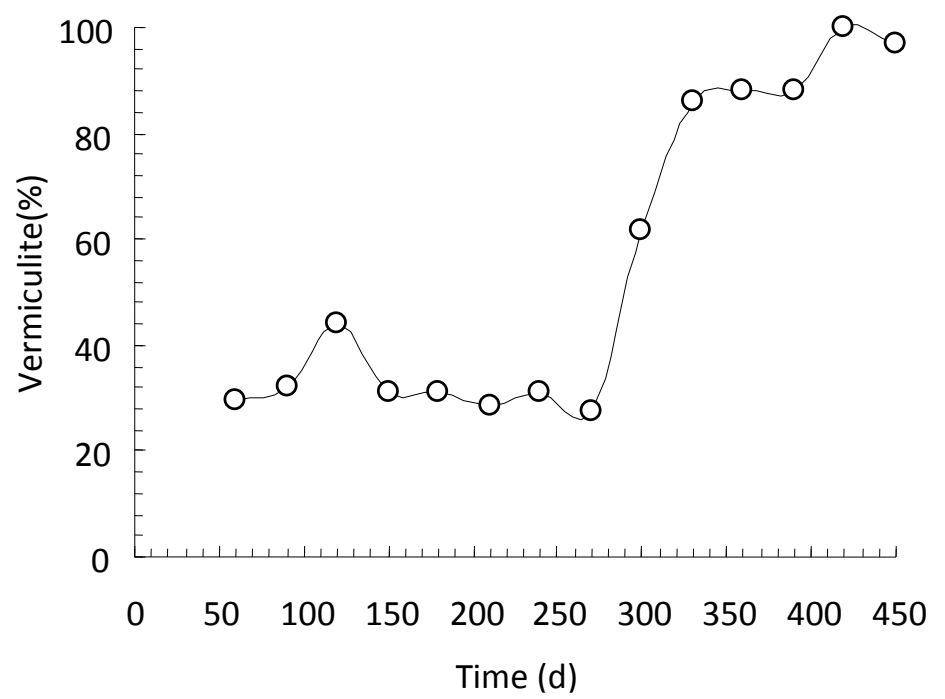

Figure 7. Temporal change of vermiculite percentage in the hydrobiotite

\section{Hydration of biotite}

Biotite sometimes weathers to hydrobiotite in which there is a regular alternation of $1.0 \mathrm{~nm}$ biotite and $1.4 \mathrm{~nm}$ vermiculite units yielding distinct $\mathrm{X}$-ray reflections at 1.2 and $2.4 \mathrm{~nm}$ (Farmer and Wilson, 1970). However, complete regular interstratification has previously only been achieved by reversing the reaction in which vermiculite is reverted to a mica-like phase (Farmer and Wilson, 1970). This study implies that hydrobiotite with irregular interstratification is perhaps more common than regular interstratified hydrobiotite. For instance, vermiculite from Tseganbrak Xinjiang, the largest vermiculite deposit in China, consists mostly of irregular phlogopite and vermiculite layers (Xu and Cao, 1993). Different cations are present in the interlayer regions of biotite and vermiculite, with $\mathrm{K}^{+}$predominant in biotite, and $\mathrm{Mg}^{2+}$ in vermiculite. In this study, the formation of hydrobiotite would be explained if $\mathrm{K}^{+}$were replaced by a small quantity of hydrated $\mathrm{Mg}^{2+}$, leading to modification of the layer structure and lowering the overall layer charge deficit. Here, the $\mathrm{Mg}^{2+}$ was derived from the original biotite and SB culture. Biotite and vermiculite are both phyllosilicates with a similar 2:1 structure type. Thus, the vermiculite might be formed in a layer-by-layer transformation (Murakami et al., 2003), causing the interlayer distance to increase from $1.00 \mathrm{~nm}$ to $1.49 \mathrm{~nm}$ structural expansion in the crystallographic c-axis direction. The neoformed vermiculite layers and relict biotite layers constitute a hydrobiotite with irregular interstratification. The increase of interlayer distance up to $1.49 \mathrm{~nm}$ on day 420 indicates that a part of the biotite flakes were almost completely transformed into vermiculite. 
Previous studies have indicated that weathering takes place mainly at the edges of the biotite grains and from the edges parallel to the crystal face (001) inward to a depth of a few tens to hundreds of micrometers (Murakami et al., 2003). Thus, the weathering rate at the edges is two orders of magnitude larger than at the basal surface (Turpault and Trotignon, 1994). The transformation of the fine biotite flakes into vermiculite is more rapid due to the larger specific surface area than is available in the thick flakes. In other words, an irregular interstratification structure consisting of biotite and vermiculite is likely to form when $\mathrm{K}^{+}$around the edges of the biotite flake is replaced by hydrated $\mathrm{Mg}^{2+}$.

\section{Conclusions}

When it is produced in the laboratory, verification of the weak crystalline nature of a mineral comes from XRD analysis, Fourier-transform infrared analysis, thermogravimetric analysis, and/or from Raman spectroscopy. Such analyses are possible because the weak crystalline mineral is the only phase present. If the weak crystalline mineral is present in company with a fine crystalline mineral, however, its detection by XRD or any other analytical method becomes problematical, especially if the fine crystalline mineral constitutes only a small proportion of the total precipitate. Secondary clay minerals (e. g. vermiculite) are more weakly crystalline than a primary silicate mineral such as biotite, making it difficult to obtain information about any secondary minerals from XRD patterns of the whole precipitate. The results of the present study suggest that separating of thin fractions (especially, less than $1 \mu \mathrm{m}$ ) from the solid residue is a practicable approach. In addition, we draw the following two conclusions:

(1) In the biotic and abiotic experiments, hydrobiotite appeared in the fraction with grain sizes less than $1 \mu \mathrm{m}$ on days 60 and 390, respectively. In other words, strain YM-1 of Paenibacillus mucilaginous evidently accelerated biotite weathering.

(2) Hydrobiotite is an irregularly interstratified mineral consisted of layers of neoformed vermiculite and relict biotite. In the biotic experiments, the vermiculite layer content in the hydrobiotite gradually increased with incubation time from about $30 \%$ on day 60 until to about $100 \%$ on day 420 .

In other words, using enrichment method and XRD technology, researchers have the opportunity to get information about the formation of secondary minerals more clearly than the previous applied process. This method is very helpful for research on the weathering of minerals and rocks in the nature, especially, on the microbe-mineral interactions in laboratory.

Acknowledgments. This work was supported by the National Science Foundation Project of China (grant Nos. 40573057 and 41673083), Open Project of the State Key Laboratory of Loess and Quaternary Geology (grant No. SKLLQG1511). We thank International Science Editing (http://www.internationalscienceediting.com) for editing this manuscript.

\section{REFERENCES}

[1] Ahmed, E., Holmström, S. J. M. (2015): Microbe-mineral interactions: the impact of surface attachment on mineral weathering and element selectivity by microorganisms. Chem. Geol. 403: 13-23. 
[2] Ahn, J. H., Peacor, D. R. (1987): Kaolinitization of biotite: TEM data and implications for an alteration mechanism. - Am. Mineral. 72: 353-356.

[3] Balogh-Brunstad, Z., Keller, C. K., Dickinson, J. T., Stevens, F., Li, C. Y., Bormann, B. T. (2008): Biotite weathering and nutrient uptake by ectomycorrhizal fungus, Suillus tomentosus, in liquid-culture experiments. - Geochim. Cosmochim. Acta 72: 2601-2618.

[4] Banfield, J. F., Eggleton, R. A. (1988): Transmission electron microscope study of biotite weathering. - Clay. Clay Miner. 36: 47-60.

[5] Banfield, J. F., Murakami, T. (1998): Atomic-resolution transmission electron microscope evidence for the mechanism by which chlorite weathers to $1: 1$ semi-regular chlorite-vermiculite. - Am. Mineral. 83: 348-357.

[6] Barker, W. W., Welch, S. A., Chu, S., Banfield, J. F. (1998): Experimental observations of the effects of bacteria on aluminosilicate weathering. - Am. Mineral. 83(12): 15511563.

[7] Bennett, P. C., Hiebert, F., Rogers, J. R. (2000): Microbial control of mineralgroundwater equilibrium: macroscale to microscale. - Hydrogeol. J. 8:47-62.

[8] Bonneville, S., Morgan, D. J., Schmalenberger, A., Bray, A., Brown, A., Banwart, S. A., Benning, L. G. (2011): Tree-mycorrhiza symbiosis accelerate mineral weathering: evidences from nanometer-scale elemental fluxes at the hypha-mineral interface. Geochim. Cosmochim. Acta 75: 6988-7005.

[9] Bray, A. W., Oelkers, E. H., Bonneville, S., Wolff-Boenisch, D., Potts, N. J., Fones, G., Benning, L. G. (2015): The effect of $\mathrm{pH}$, grain size and organic ligands on biotite weathering rates. - Geochim. Cosmochim. Acta 164: 127-145.

[10] Dong, H., Peacor, D. R., Murphy, S. F. (1998): TEM study of progressive alteration of igneous biotite to kaolinite throughout a weathered soil profile. - Geochim. Cosmochim. Acta 62: 1881-1887.

[11] Ehrlich, H. L. (1996): How microbes influence mineral growth and dissolution. - Chem. Geol. 132: 5-9.

[12] Emberson, R., Galy, A., Hovius, N. (2017): Combined effect of carbonate and biotite dissolution in landslides biases silicate weathering proxies. - Geochim. Cosmochim. Acta 213: 418-434.

[13] Farmer, V. C., Wilson, M. J. (1970): Experimental conversion of biotite to hydrobiotite. Nature 226: 841-842.

[14] Föllmi, K. B., Arn, K., Hosein, R., Adatte, T., Steinmann, P. (2009): Biogeochemical weathering in sedimentary chronosequences of the Rhône and Oberaar Glaciers (Swiss Alps): Rates and mechanisms of biotite weathering. - Geoderma 151: 270-281.

[15] Fortin, D., Beveridge, T. J. (1997): Role of the bacterium Thiobacillus in the formation of silicates in acidic mine tailings. - Chem. Geol. 141: 235-250.

[16] Frankel, L. (1977): Microorganisms induced weathering of biotite and hornblende grains in estuarine sands. - J. Sediment. Petrol. 47: 849-854.

[17] Huang, Z., He, L., Sheng, X., He, Z. (2013): Weathering of potash feldspar by Bacillus sp. L11. - Acta Microbiol. Sinica 53(11): 1172-1178 (in Chinese with English abstract).

[18] Kalinowski, B. E., Schweda, P. (1996): Kinetics of muscovite, phlogopite and biotite dissolution and alteration at $\mathrm{pH} 1-4$, room temperature. - Geochim. Cosmochim. Acta 60: 367-385.

[19] Karavaiko, G. I. (1997): Description of a new species of mucilaginosus bacteria, Bacillus edaphicus sp. Nov., and conformation of the taxonomic status of Bacillus mucilaginosus based on data of phenotypic and genotypic analysis. - Microbiologiia 66: 813-822.

[20] Kretzschmar, R., Robarge, W. P., Amoozegar, A., Vepraskas, M. J. (1997): Biotite alteration to halloysite and kaolinite in soil- saprolite profiles developed from mica schist and granite gneiss. - Geoderma 75: 155-170.

[21] Lu, Q., Lei, X., Liu, H. (1993): Study of the stacking sequences of a kind of irregular mixed-layer illite-smecite (I/S) clay mineral-with a discussion of the existence of 
minerals with two-dimensional lattice and one dimensional lattice quasi-lattice. - Acta Geol. Sinica 67(2): 123-130 (in Chinese with English abstract).

[22] Murakami, T., Utsunomiya, S., Yokoyama, T., Kasama, T. (2003): Biotite dissolution processes and mechanisms in the laboratory and in nature: early stage weathering environment and vermiculitization. - Am. Mineral. 88: 377-386.

[23] Murphy, S. F., Brantley, S. L., Blum, A. E., White, A. F., Dong, H. (1998): Chemical weathering in a tropical watershed, Luquillo Mountains, Puerto Rico: II. Rate and mechanism of biotite weathering. - Geochim. Cosmochim. Acta 62: 227-243.

[24] Rogers, J. R., Bennett, P. C. (2004): Mineral stimulation of subsurface microorganisms: release of limiting nutrients from silicates. - Chem. Geol. 203: 91-108.

[25] Samson, S. D., Nagy, K. L., Cotton, W. B. (2005): Transient and quasi-steady-state dissolution of biotite at $22-25^{\circ} \mathrm{C}$ in high $\mathrm{pH}$, sodium, nitrate, and aluminate solutions. Geochim. Cosmochim. Acta 69: 399-413.

[26] Setiawati, T. C., Mutmainnah, L. (2016): Solubilization of potassium containing mineral by microorganisms from sugarcane rhizosphere. - Agr. Agr Sci. Procedia 9: 108-117.

[27] Shelobolina, E. S., Avakyan, Z. A., Boulygina, E. E., Tourova, T. T., Lysenko, A. M., Osipov, G. A., Tamrat, W. Z., Rose, J., Grauby, O., et al. (2018): Composition and molecular scale structure of nanophases formed by precipitation of biotite weathering products. - Geochimica et Cosmochimica Acta 229: 53-64.

[28] Turpault, M. P., Trotignon, L. (1994): The dissolution of biotite single crystals in dilute $\mathrm{HNO}_{3}$ at $24^{\circ} \mathrm{C}$ : evidence of an anisotropic corrosion process of micas in acidic solutions. - Geochim. Cosmochim. Acta 58: 2761-2775.

[29] Ward, M. B., Kapitulcinova, D., Brown, A. P., Heard, P. J., Cherns, D., Cockell, C. S., Hallam, K. R., Ragnarsdottir, K. V. (2013): Investigating the role of microbes in mineral weathering: nanometre-scale characterisation of the cell-mineral interface using FIB and TEM. - Micron 47: 10-17.

[30] Webb, H. N., Girty, G. H. (2016): Residual regolith derived from the biotite-controlled weathering of Cretaceous tonalite-quartz diorite, Peninsular Ranges, southern California, USA: a case study. - Catena 137: 459-482.

[31] White, A. F., Brantley, S. L. (2003): The effect of time on the weathering of silicate minerals: why do weathering rates differ in the laboratory and field? - Chem. Geol. 202: 479-506.

[32] Xu., R., Cao, J. (1993): A mineralogical study of vermiculite from Tseganbrak Xinjiang. - Acta Mineral. Sinica 13(1): 37-45 (in Chinese with English abstract).

[33] Zavarzina, D. G., Chistyakova, N. I., Shapkin, A. V., Savenko, A. V., Zhilina, T. N., Kevbrin, V. V., Alekseeva, T. V., Mardanov, A. V., Gavrilov, S. N., Bychkov, A. Y. (2016): Oxidative biotransformation of biotite and glauconite by alkaliphilic anaerobes: the effect of $\mathrm{Fe}$ oxidation on the weathering of phyllosilicates. - Chem. Geol. 439: 98109. 